\title{
The Effect of Blackboard Learning on the Development of English Writing Skills among University Students
}

\author{
Dr. Mohammad Abd Alhafeez Ali Ta'amneh \\ Associate Professor of Teaching English as a Foreign Language (TEFL), Taibah University
}

\begin{abstract}
This study investigated the effect of Blackboard platform on the development of students' writing skills in English. It employed a quasi-experimental design followed by qualitative interviews. The sample consisted of seventy students enrolled in the second semester of the academic year 2019/2020. They were divided equally into two groups (experimental and control). The experimental group was taught through Blackboard platform whereas the control group learned through conventional lectures. The researcher prepared a writing achievement test depending on the basic information needed to deal with English writing course ( ENGL 104) taught at Taibah University. The two groups were pre-post tested using a writing achievement test. The researcher analyzed data through Statistical Package for Social Sciences(SPSS). Twenty students in the experimental group were interviewed to identify their perceptions about Blackboard learning. Results revealed that Blackboard learning was effective in developing and improving the writing skills of the experimental group. The results also revealed a positive attitude towards Blackboard learning. The researcher recommended other researchers to conduct similar studies by using different sample in other areas and other language skills to determine the effect of Blackboard learning on English language learning.
\end{abstract}

Keywords: Blackboard learning, educational technologies, online learning, Learning Management System.

DOI: $10.7176 / \mathrm{JEP} / 11-19-12$

Publication date:July $31^{\text {st }} 2020$

\section{Introduction}

Technology can be a very important instrument for making a new shape of learning. It can change old learning approaches and techniques to meet learners' needs and improve their educational experiences. To know the benefits of technology in educational processes, both learners and instructors have to use it efficiently and successfully in their practices. They have to know the requirements and instructions needed to deal with any technological software. Universities and other learning centers, on the other hand, should work with their instructors and students to achieve their objectives and make the process of using technology easy and successful. Learning Management Systems (LMSs) are e-learning platforms based on the internet and helps teachers " to manage materials distribution, assignments, communications and other aspects of instructions for their courses" (Abu Shawar, 2009, p. 3). Nowadays, LMSs have become an essential element of the learning processes in most academic institutes and learning centers (Pishva, Nishantha, and Dang, 2010). The main role of using this kind of learning is to enhance the traditional learning with online contents (Landry, Griffeth, and Hartman ,2006).

The adoption of a learning management system in universities has modified educational strategies and techniques. Some educational institutions advise instructors and students to use online systems in their educational practices such as Blackboard because they have the potential to offer a useful and suitable online support to the traditional classroom teaching methods (Black, 2008). One of the most important role of the instructors is to help students understand their materials and achieve their objectives successfully. Sometimes the instructors need extra information and more time to achieve the objectives of the course. More to this point, some students need more time to discuss many points with their instructors to achieve the desirable goals. Integrating online technological systems in learning gives learners and instructors more educational benefits and help them to overcome the drawbacks of traditional learning through discussing, explaining and exchanging educational ideas related to their courses outside the classroom at any time (Ta'amneh, 2017). The Saudi universities have started to integrate blended learning models to enhance and develop the traditional learning done inside their campuses. They understand the importance of online communication in facilitating the educational processes. The implementation of online learning helps teachers and learners to communicate and collaborate outside the classrooms and increases some innovative methods of teaching and learning.

EFL students face a lot of obstacles that prevent them from making successful communication in English such as the effect of the first language, insufficient use of English language in real life situations, the absent of communication in English, and the lack of using modern technological online tools (Al-Nasser, 2015).Furthermore, "They depended on their teachers' explanations and did not like to spend their time in applying new strategies in learning new English regardless the benefits which they gained from these strategies" (Ta'amneh, 2014,p. 157).So, the roles of the instructors need to be modified to be more flexible in dealing with courses through using new technological tools inside and outside the classrooms. 


\section{Statement of the Problem}

Blended learning model provides learners with many innovative learning and teaching strategies needed to share and collaborate their knowledge outside the classrooms. Both students and instructors can use this model to enhance their interactions and to reconstruct their learning and teaching practices in English. Taibah University has adopted a new blended learning model (learning through Blackboard) to facilitate and reinforce students' learning. The adoption of Blackboard model has motivated the researcher to study its potential in introducing English writing information to the students. The effectiveness of Blackboard learning depends on the supplementary online English writing components and how these components can improve students' achievements. There are a few studies examining the impact of new technology on the process of learning in the kingdom of Saudi Arabia (AlAjmi et al. 2012). Most of them have concentrated on the theoretical perspectives. Accordingly, more experimental researches are required to know the effect of modern technology such as learning through Blackboard on students' achievements (Hussein 2016). As a teacher of English writing courses for many years at Taibah University, the researcher observed that the achievements of some EFL students in writing skills are below the accepted level. They lack the basic writing skills needed to communicate with others. However, the researcher aims to discover the effectiveness of using Blackboard model on students' achievements in English writing skills.

\section{Significance of the Study}

The major aim for carrying out this research is to improve the writing performance among university students at Taibah University then deciding the effect of Blackboard learning on such performance since the integration of technology in teaching English writing may help students to improve and develop their writing performance. The significance of this study stems from the fact that there are not many studies investigated the impact of Blackboard learning in teaching English writing skills among university students. The results o current study may provide instructors and students with good ideas about using blackboard in educational setting. It may also provide educational institutions and decision makers with the challenges faced users while using this kind of learning, especially while using the system, doing online exams, quizzes and assignments, and recognizing the requirements of dealing with this system. In the same vein, this study may provide the educational planners with improvements needed to make Blackboard learning effective and valuable. Finally, this study may help other researchers to investigate the effect of Blackboard learning on students' achievements with different variables which are not included in this study.

\section{Purpose of the Study}

The current study aimed at investigating the effectiveness of Blackboard instruction on developing students' English writing skills, and to illustrate whether blackboard can provide an effective way of improving the learners' writing skills.

\section{Questions of the Study}

This study attempted to answer the following questions:

1. What is the effect of Blackboard learning on the students' achievement in the English writing skills?

2. Which is more effective Blackboard or traditional learning in improving students' writing achievements?

\section{Limitations of the Study}

The generalization of this study is limited due to the following factors:

1. The instruments of the study are limited to the achievement writing test and the interview with students.

2. The context is limited to Taibah University (Badr Branch) only.

3 . The duration of the program is eight weeks within two months, started on $26 / 1 / 2020$ till

20/3/2020.

4. Both groups (experimental and control) were taught by the researcher.

\section{Definition of Terms}

Blackboard Learning: It is a learning that depends on the e-learning management system which includes a set of characters that enable students to communicate with other participants synchronously and asynchronously.

Educational Technologies: They are technologies used in the field of education that enhance students learning and improve their performance.

Online Learning: It is a learning that takes place over the internet and enables students to learn outside the traditional learning environment.

Learning Management System: It is an e-learning system that helps students to learn and communicate effectively in the virtual learning environments to improve and develop their overall learning. 


\section{Literature Review}

The growth of educational applications in higher education leads universities and academic institutions to invest seriously in different Learning Management Systems to deal with electronic learning services (Chang, 2013; Caputi \& Garrido, 2015). Some researchers consider Learning Management Systems ,like Blackboard, as useful and effective kinds of e-learning systems for both teachers and learners in educational setting (Liaw, 2008; Chang, 2013). LMS gives instructors various online courses and a lot of features that help them to communicate with learners anytime and everywhere. They can post students' grades, exams and quizzes (Chang, 2013). Learning through LMS changes students' thinking towards the process of learning. It motivates them to communicate online with others and with their teachers in different ways (Liaw, 2008; Tella, 2011). It also "provides the means for changing the way of thinking in which the learning materials are brought to learners" (Ta'amneh ,2014 p.184) .Blackboard is considered to be one of the software packages used to facilitate the process of learning (Beatty and Connie, 2006). The following is a number of studies investigated the role of blended learning in general and blackboard learning in specific in improving English writing skills among university students.

Kashghari \& Asseel (2014) carried out a study to find the effect of Blackboard Collaborate on the EFL students' communication skills in the department of European Languages in King Abdulaziz University. Seventeen female students were participated in this study. The instructors used blackboard learning to motivate using English among students and to encourage them to communicate in English language. The participants completed a survey after listening and speaking online assessments. The results indicated that the students' listening skills were improved after using blackboard learning but the participants were uncertain whether their speaking skills were improved or not. In addition, The researchers found that there were a lot of advantages of using blackboard in learning such as the easy access of course material, simplicity of Blackboard instructions, and the effectiveness of utilizing computers and mobiles rather than conventional use of exam sheets. on the other hand, They found some drawbacks connecting with blended learning such as technical problems, lack of students' training, and the lack of labs.

In the same vein, Mohsen \& Shafeeq (2014) investigated instructors' perceptions about using Blackboard applications in teaching English. The participants consisted of thirty two EFL university teachers from Saudi Arabia. They were surveyed and interviewed to identify their perceptions about blackboard learning. The results showed that the participants had positive opinions about the effectiveness of Blackboard applications in teaching English language. They agreed that Blackboard platform improved the communication between teachers and students and helped them in making the process of teaching English more effective and successful. However, the results revealed that using blackboard learning was not concentrated on pedagogical significance for language learning, it focused mainly on administrative issues.

In their study, Geta \& Olango (2016) examined the role of blended learning in improving students' English writing performance and explored EFL instructors' attitudes towards using such learning to teach writing skills. The participants consisted of eighty students and fifty EFL instructors. Two groups were assigned for the students. The first(experimental) group was assigned to learn through blended learning model while the second (control) group was learned through lectures ( traditional learning). The researcher collected data from students through applying pre-test and posttest while questionnaire and FGD were used for EFL teachers. Concerning students' groups, results revealed that the experimental group had better results in the posttest results. EFL instructors had positive attitudes towards blended learning and using computers but their use of them was moderate.

Hussein (2016)investigated the effect of Blackboard learning on students' achievements at Bisha University. Forty students were divided equally into two groups. The experimental group learned through Blackboard Collaborate, while the control group learning depended on the traditional instruction. Results showed that the instruction depended on Blackboard learning was effective and successful in improving the achievements of the experimental group. Besides, it helped students in improving their achievements through giving them actual opportunities to communicate successfully with their instructors, peers, and online activities.

Similarly, AlHassan \& Shukri (2017) investigated the effectiveness of using Blackboard instruction on enhancing Saudi students' satisfaction. Ninety-eight students were participated in this study. The researcher used a questionnaire to know students' level of satisfaction. The results showed that that students' responses were positive concerning their satisfaction in terms of educational resources, communication in English language, suitability and diversity of content, and simplicity of using Blackboard. It was discovered that using the supplementary materials and online activities on the Blackboard helped students in their learning and improved their performance.

Using a sample of Bisha University students, Ali (2017) investigated the role of Blackboard system in motivating Saudi EFL students. He tried to recognize the effects of Blackboard learning on the students' motivation depending on their perspectives. Eighty EFL students from the English Department at Bisha University in the Kingdome of Saudi Arabia. The results revealed that the participants were motivated and learned better when they used Blackboard platform in their English learning. It also showed that students' motivation increased after using technical skills needed to deal with Blackboard system and consequently became fluent in using educational 
technology. However; the study mentioned some factors that decreased motivation among EFL students while using Blackboard instruction.

Mofrad (2017) investigated the efficiency of blended learning in improving writing skills among EFL students. Sixty students were divided into four groups depended on the their learning style (blended learning and conventional classes). The participants practiced online educational technology in their learning. The results revealed that the participants who used blended learning in their instruction were better than students in the conventional classes.

Using a sample of Prince Sattam bin Abdulaziz University students, Kassem (2018) explored the effects of utilizing Blackboard instruction on EFL students' writing proficiency and observed their attitudes towards such instruction. The researcher used three indicators (accuracy, fluency and complexity) to estimate participants' writing proficiency. Thirty students were chosen randomly and asked to respond to a questionnaire . Results showed positive effects of using Blackboard platform in improving EFL students' writing proficiency. Besides, they revealed a positive attitude towards utilizing such platform.

In the same vein, Wahyuni (2018) explored the effect of blended learning on the students' writing ability at Pekanbaru. The sample was divided into experimental and control groups. The instructor used blended learning application (Telegram Messenger) to teach the first group (experimental) whereas the traditional learning (lecture) was used for the control group. The researcher used writing test for both groups. Results revealed that the experimental group had better results in the post-test than the control group. It was also found that the participants' writing performance was affected by blended learning model used in this study.

Basabrin (2019) explored the perceptions of written corrective feedback on Blackboard application among EFL instructors and students. Four participants were participated in this study (three students and their EFL instructor). The researcher followed a qualitative design in this study. The results revealed that learners' personal factor depended on their feedback choices concerning feedback amount, type, and level. It also showed that the learners' attitudes towards learning through blackboard were positive.

Finally, Alamer (2020) investigated the impact of using Blackboard learning on students' attitudes at King Khalid University. The study also investigated their information and abilities in utilizing the Blackboard in their learning, and analyzed the elements affected their attitudes in using Blackboard instruction inside and outside classrooms depending on their opinions. The sample was consisted of thirty four of students at KKU. The results showed that the participants faced a lot of challenges and difficulties in the implementation of blackboard in their learning as a result of negative thoughts concerning vocabulary items. It also found that such learning had a little impact on the participants' attitudes in learning English vocabulary items.

The above studies suggest that using Blackboard learning management system for learning English language skills provide many positive outcomes and enhance the process of language learning. However, very few studies investigated the effect of such learning on the development of students' writing skills in English. To the best knowledge of the researcher, there was no focus on the effect of Blackboard learning on university students' writing skills. This study aimed at investigating the effect of this kind of online learning on the improvement of English writing skills among university students and to discover their perspectives about using such learning during the experiment.

\section{Methods and Procedures}

9.1 Design of the Study

This mixed-methods study followed a quasi-experimental design and qualitative interviews. The participants were divided into two groups (experimental and control). There are two variables in this study ; independent variable (learning through Blackboard system ,blended learning) and dependent variable (students' writing performance). Both groups had the same number of participants (thirty five students in each group). It also followed qualitative interviews.

\subsection{Participants of the Study}

The participants of this study,who were chosen purposefully, consisted of seventy students enrolled in the second semester of the academic year 2019/2020 in English writing course (ENGL104) taught at Taibah University $\backslash B a d r$ Branch in the Kingdom of Saudi Arabia. The seventy participants were divided equally into two groups (experimental and control). The participants in the experimental group were learned through Blackboard instruction where the traditional method combined technology. During the meetings of learning, students were given online examples, exercises, quizzes and assignments through Blackboard instruction. In contrast, the participants in the control group were taught according to the guidelines suggested by the book. All participants were given the same writing tests to show the equivalence among groups, the pre-test was given for both groups. At the end of the training, the post-test was given to the participants to assess their progress in writing. Twenty students in the experimental group were interviewed to identify their perceptions about the Blackboard learning. 
9.3 Instruments of the Study

9.3.1 Instruments

Two instruments were used in this study: semi-structured interviews and pre and posttests. The researcher designed a writing test to evaluate students' achievements in English writing. It consisted of twenty items. All students participated in this study answered the pre-test. After eight weeks of the learning, the post-test was given to them to find their improvements in writing. Moreover, the researcher interviewed twenty students to know their opinions about the effectiveness of learning English writing skills through Blackboard instruction.

9.3.2 Validity and Reliability of the Instruments

The writing test and the interview questions were submitted to a jury of eight professors to give their suggestions and make the necessary modifications. Accordingly, some items were modified or deleted and other new items were added. Concerning the reliability for the test, the researcher selected fifteen students to be tested twice with a two-week interval between them. The reliability coefficient was calculated using Cronbach Alpha. The calculated value was .81 which is enough to conduct this study. The researcher also asked the same students to look to the interview questions and give their suggestions about the clarity of the items.

\subsection{Procedures}

The researcher used Blackboard platform found on the website of Taibah University to enhance students' writing performance through supplementary online writing materials for the experimental group. The control group was only taught through traditional way (conventional lectures) of teaching by the same instructor.

This study was conducted at Taibah University in the Kingdom of Saudi Arabia during the second semester of the academic years 2019/2020. The researcher obtained a permission of the participants after explaining the objectives of the study to do this research. Besides, the researcher prepared the writing test before the experiment. The seventy participants were divided into two groups (experimental and control). Afterwards, the researcher gave both groups details and instructions about the experiment.

During the eight weeks of learning, the experimental group learned their English writing course (ENGL 104) through Blackboard instruction whereas the control group learned the same course through traditional instruction. After that, the pre-test was given to both groups. After eight weeks, the post-test was given to the participants. The results were discussed depending on the data obtained from the participants. The scores were analyzed statistically using Statistical Package for Social Studies (SPSS). Twenty students were interviewed to explore their perceptions about the effectiveness of using Blackboard instruction in improving their English writing skills. The questions of the interview were semi-structured and focused on the benefits and contributions of Blackboard instruction in improving students’ English writing comparing with traditional learning.

\section{Data Analysis}

The researcher corrected the writing tests depended on the number of items, each item had one point. The total is 20 out of 20. The Statistical Package for the Social Sciences (SPSS) was used to find the following:

- Cronbach's Alpha.

- Means and standard deviations of the participants' performance in the pre and posttests.

- Independent-Samples T-test to discover the significance differences between the experimental and control groups.

\section{Results}

Concerning the first question " What is the effect of Blackboard leaning on the students' achievement in the English writing skills?", the mean scores and standard deviations of the students' scores on the writing pre-test were calculated, as shown in Table 1.

Table 1. Means and standard deviations of performance in pre- achievement test

\begin{tabular}{|c|c|c|c|c|c|}
\hline Method & Group & $\mathrm{N}$ & Mean & Std. Deviation & Std. Error Mean \\
\hline \multirow{3}{*}{ Pre-test } & Experimental & 35 & 16.80 & 2.349 & .397 \\
\cline { 2 - 6 } & Control & 35 & 16.20 & 4.057 & .686 \\
\hline
\end{tabular}

The above table shows that there were small differences between the means of experimental group (16.80) and control group (16.20 ) in the pre-achievement test. Independent Sample T- Test was estimated to make a decision if these differences had statistical significance as shown in Table 2. 
Table 2. Independent Samples T- Test results of the differences between the means of pre-achievement test

\begin{tabular}{|c|c|c|c|c|c|c|c|c|c|c|}
\hline & \multicolumn{2}{|c|}{$\begin{array}{c}\text { Levene's Test for } \\
\text { Equality of } \\
\text { Variances }\end{array}$} & \multicolumn{7}{|c|}{ t-test for Equality of Means } \\
\hline & & \multirow[t]{2}{*}{$\mathrm{F}$} & \multirow[t]{2}{*}{ Sig. } & \multirow[t]{2}{*}{$\mathrm{t}$} & \multirow[t]{2}{*}{ df } & \multirow[t]{2}{*}{$\begin{array}{l}\text { Sig. (2- } \\
\text { tailed) }\end{array}$} & \multirow[t]{2}{*}{$\begin{array}{c}\text { Mean } \\
\text { Difference }\end{array}$} & \multirow[t]{2}{*}{$\begin{array}{l}\text { Std. Error } \\
\text { Difference }\end{array}$} & \multicolumn{2}{|c|}{$\begin{array}{l}95 \% \text { Confidence } \\
\text { Interval of the } \\
\text { Difference }\end{array}$} \\
\hline & & & & & & & & & Lower & Upper \\
\hline Pretest & $\begin{array}{c}\text { Equal } \\
\text { variances } \\
\text { assumed } \\
\text { Equal } \\
\text { variances not } \\
\text { assumed }\end{array}$ & 3.429 & .068 & 757 & 54.493 & .452 & .600 & .792 & $-.981-$ & 2.181 \\
\hline
\end{tabular}

Table 2 shows that there were no statistically significant differences between the means of the pre-academic achievement test since the significant value (Sig. $=0.452)$ was more than $0.05(\alpha \leq 0.05)$. The above table also shows that the both groups were equal and almost alike since the calculated significant in Levene's test value (sig $=0.068)$ was more than $0.05(\alpha \leq 0.05)$.

Table 3. Means and standard deviations of performance in the post-achievement test

\begin{tabular}{|l|c|c|c|c|c|}
\hline Method & $\mathrm{N}$ & Mean & Std. Deviation & Std. Error Mean \\
\hline \multirow{3}{*}{ Posttest } & Experimental & 35 & 19.46 & .701 & .118 \\
\cline { 2 - 6 } & Control & 35 & 17.69 & 4.594 & .777 \\
\hline
\end{tabular}

Table 3 shows that there were differences between the means of experimental group (19.46) and control group (17.69) in the post-achievement test in favor of the experimental group. The researcher used the Independent Sample T- Test to make a decision if such differences had statistical significance or not, as indicated in Table 4. Table 4. Independent Samples T- Test results of the differences between the scores' means of post-achievement test

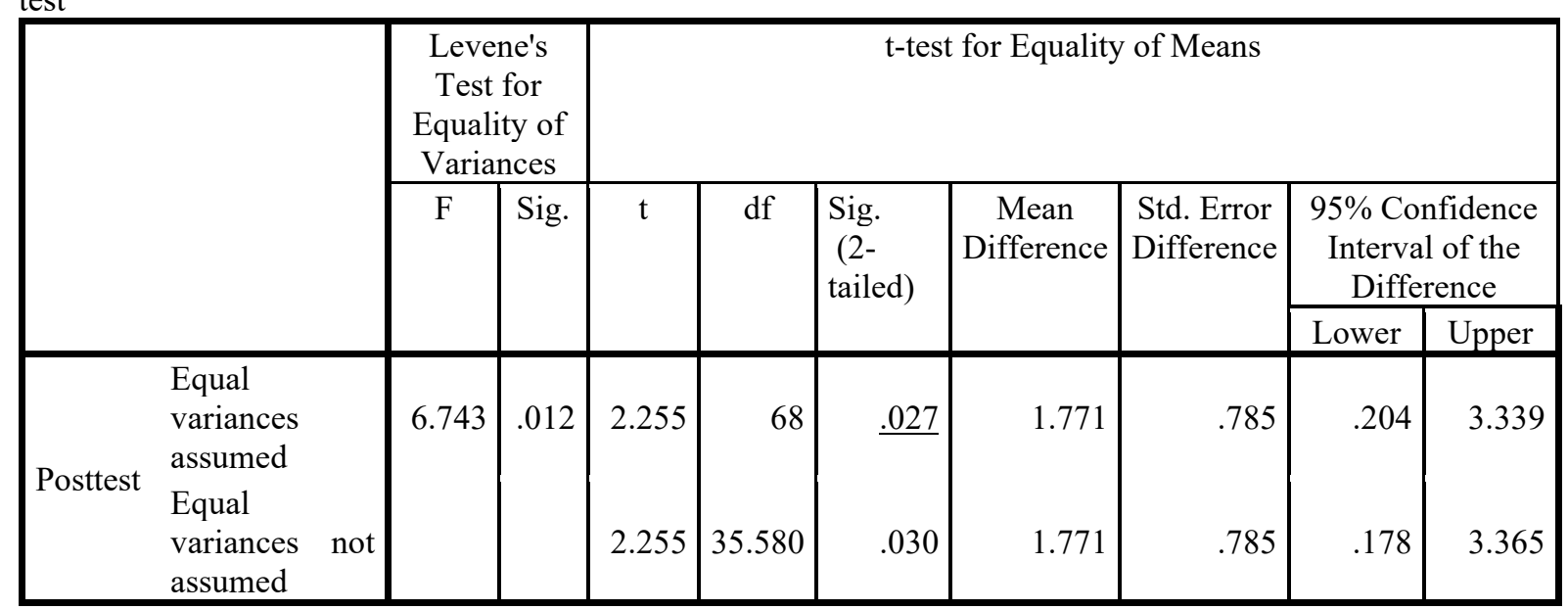

Table 4 shows statistically significant differences in the post academic achievement test. The differences were statistically significant since the significant value (.027) was less than $0.05(\alpha \leq 0.05)$. Levene's test for equality of variances confirmed that that the two groups were not equal because the significant value (.012) was less than $0.05(\alpha \leq 0.05)$.

The results of the mean scores of the both groups (experimental and control) revealed that the mean scores of the post test of the experimental group were better than those of the control group. The post test results indicated significant differences between the two groups in favor of the experimental group. This means that the participants who learned ENGL 104 (the writing course) through Blackboard instruction performed better in the writing test as a result of such learning. It can be inferred that learning English writing skills through Blackboard instruction had a positive impact on the development and improvement of the student writing skills. This result matches (Geta \& Olango ,2016; Hussein ,2016; Mofrad , 2017; Kassem , 2018; Wahyuni, 2018; and Alamer, 2020) which proved the effectiveness of blended learning in general and Blackboard learning in specific in improving students' English language skills. Whereas, it is inconsistence with Mohsen \& Shafeeq (2014) which showed that Blackboard learning was not concentrated on pedagogical significance for language learning, it focused mainly on administrative issues.

To answer the second question "Which is more effective Blackboard instruction or traditional instruction in 
enhancing students writing achievements?", the researcher interviewed twenty students of the experimental group. They were asked six questions about the effectiveness of Blackboard instruction in improving their English writing skills.

The first question aimed to discover whether students prefer to learn writing skills through Blackboard instruction or not. The students were very excited about using this kind of learning, the majority of them (eighteen students) answered that they liked learning English writing through Blackboard instruction. In contrast, two students did not like learning through Blackboard platform. They preferred learning through lectures.

The second question explored the importance of using Blackboard in learning writing skills. Seventeen students answered this question positively. They thought that using such learning was very important in facilitating the process of learning. Three students believed that traditional learning was more effective than Blackboard learning.

The third question explored whether the students were happy with this learning experience. All students were happy with their online learning. Concerning the forth question which was about the role of Blackboard instruction in helping students in their learning, all of them agreed that doing online exercises, quizzes and exams helped them in understanding the goals of the course. They thought that such learning made the learning process attractive and interesting.

The fifth question investigated the benefits and advantages of utilizing Blackboard in learning writing activities. The students' answers revealed that using this kind of learning had many advantages, such as shared information and communicated easily with instructor and other students, helped them to learn their writing course and other supplementary materials at home without going to the university campus, enabled them to listen to lectures many times so that they helped them in better understanding, attended online exams, quizzes, and exercises, motivated them to communicate synchronously and asynchronously, decreased their anxiety and enhanced their comprehension, used different learning styles in explaining English writing rules, and provided them with equal opportunities for participation.

The last question explored the disadvantages of using Blackboard in students' learning. The students' responses revealed that they faced technical problems in the internet connection, slow internet connections, lack of training in the use of Blackboard platform, and lack of technical support services.

\section{Discussion}

The above results answered the two questions of this study which are: "What is the effect of Blackboard learning on the students' achievement in the English writing skills? and Which is more effective Blackboard or traditional learning in improving students' writing achievements?" The results of the post-test of the experimental group were better and higher than those of the control group. These results showed significant differences in favour of the experimental group; which means that the participants in the experimental group performed better after the training which had a positive result on their English writing. This result proved that learning through Blackboard platform helped the students in the experimental group to get high grades and to perform better than the others found in the control group which means that this kind of learning (Blackboard learning) can enhance learners writing skills. Depending on the students' responses and opinions about the appropriate method that they preferred in learning English writing skills, the researcher categorized their responses into different themes such as advantages, disadvantages, and the role of Blackboard instruction in helping them in their learning. Their comments, explanations and opinions indicated that the students like and appreciate Blackboard learning and enjoyed online learning. They seemed to be aware of the importance of this kind of online learning. The Students' comments indicated that the purpose of the English writing course (ENGL 104) following Blackboard instruction model was achieved. They were satisfied with this learning strategy and liked studying outside the classroom (using the Blackboard platform) rather than the traditional strategy based on classroom lectures. These results are in line with the findings of Kashghari \&Asseel (2014), AlHassan \& Shukri (2017), Ali (2017), and Basabrin (2019) who mentioned the effectiveness of Blackboard platform in learning English language skills.

\section{Implications of the Study}

This study tries to discover the importance of Blackboard learning management system in improving English writing skills among university students. Several implications can help students improve their learning outcomes:

- Motivate students to use Blackboard learning management system to improve their writing skills rather than the traditional strategies based on classroom lectures.

- Train the students to use Blackboard platform correctly and purposefully, and provide them with technical support services.

- Develop new ways to solve technical problems in the internet connection and slow internet connections since this kind of learning depends primarily on the internet. 


\section{Conclusion and Recommendations}

Blackboard learning is a new strategy used in educational setting. The use of such learning in the EFL context is considered as a new approach to teach and learn English language skills. The current study aimed to explore the effectiveness of Blackboard platform on the development of students' writing skills in English. It also aimed to investigate their perceptions about the impact of such learning on the process of learning English writing. Results revealed that Blackboard instruction was effective in improving the English writing skills of the participants in the experimental group. The results also revealed that the students had positive pedagogical perceptions towards learning English writing skills through Blackboard instruction. Finally, more research should be conducted to discover the impact of blackboard learning on students' English language skills. It is hoped that the results of the current study help academic institutions, faculty, decision makers, and students to improve the essential skills needed for online learning.

\section{References}

Abu Shawar, B., 2009. Learning Management System and its Relationship with Knowledge Management. In: Faculty of Computer \& Information science, Ain Shams University, 4th International Conference on Intelligent Computing and Information Systems. Cairo, Egypt March 19-22, 2009

AlAjmi, M. F, Khan, S., \& Zamani, A. S. (2012). Using Instructive Data Mining Methods to Revise the Impact of Virtual Classroom in E-Learning, International Journal of Advanced Science and Technology, 45, 125-134.

Alamer, H. (2020) Impact of Using Blackboard on Vocabulary Acquisition: KKU Students' Perspective Theory and Practice in Language Studies, 10, (5), 598-603.

ALHassan, S. \& Shukri, N. (2017). The Effect of Blended Learning in Enhancing Female Students' Satisfaction in the Saudi Context. English Language Teaching.10 (9), 190-203.

Ali, J. (2017). Blackboard as a Motivator for Saudi EFL Students: A Psycholinguistic Study. International Journal of English Linguistics. 7(5). 144-151.

Al-Nasser,A.S.(2015). Problems of English Language Acquisition in Saudi Arabia: An Exploratory-cum-remedial Study. Theory and Practice in Language Studies, (Vol. 5, No. 8, pp. 1612-1619

Basabrin, A. (2018). Exploring EFL Instructors and Students Perceptions of Written Corrective Feedback on Blackboard Platform: A Case Study. Arab World English Journal, Special Issue 1: Application of Global ELT Practices in Saudi Arabia.178-191.

Beatty, B., \& Connie U. (2006). Faculty perspectives on moving from Blackboard to the Moodle learning management system. TechTrends, 50(4), 36-45.

Caputi, V., \& Garrido, A. (2015). Student-oriented planning of e-learning contents for Moodle. Journal of Network and Computer Applications, 53, 115-127.

Chang, C. (2013). Exploring the determinants of e-Learning systems continuance intention in academic libraries. Library Management, 34(1), 40-55.

Geta,M. \& Olango,M(2016).The impact of blended learning in developing students' writing skills: Hawassa University in focus. African Educational Research Journal. 4(2), 49-68.

Hussein, H.(2016).The Effect of Blackboard Collaborate-Based Instruction on Pre-service Teachers' Achievement in the EFL Teaching Methods Course at Faculties of Education for Girls. English Language Teaching, 9(3), 49-76.

Kashghari, B., \& Asseel, D. (2014). Collaboration and Interactivity in EFL Learning via Blackboard Collaborate: A Pilot Study. Paper presented at the International Conference ICT for Language Learning, 13 - 14 November 2014, Lungarno del Tempio 44, Florence.

Kassem, M. ( 2018). The Effect of Using Blackboard on English Majors' Writing Proficiency and Attitudes. International Journal of Applied Linguistics \& English Literature. 7 (6), 73-79.

Landry, B., Griffeth, R. and Hartman,S.(2006). Measuring Student Perceptions of Blackboard Using the Technology Acceptance Model. Decision Sciences Journal of Innovative Education,4 (1), pp. 87-99.

Liaw, S. (2008). Investigating students' perceived satisfaction, behavioral intention, and effectiveness of eLearning: a case study of the Blackboard system. Computers \& Education, 51(2), 864-873.

Mofrad, E. (2017). Enhancing EFL Learners' Writing Capability in a Blended Learning Environment: The Effects of Learning Styles. International Journal of English Language \& Translation Studies. 5(3). 201-209.

Mohsen,M. \& Shafeeq, P.(2014). EFL Teachers' Perceptions on Blackboard Applications. English Language Teaching. 7 (11),108-118.

Pishva, D., Nishantha, D. and Dang, A. (2010). A Survey on How Blackboard is Assisting Educational Institutions around the World and the Future Trends. In: 12th International Conference on Advanced Communication Technology (ICACT). Phoenix Park, Korea, Feb. 7-10, 2010. IEEE.

Ta'amneh, M. (2014). Investigating Vocabulary Learning Strategies used by Pre-Service Teachers at Taibah University in learning English Vocabulary Items. International Interdisciplinary Journal of Education, 3, (3), $153-158$. 
Ta'amneh, M. (2014). The Effect of Using Educational Websites on First Year Students' Achievement in English Grammar in Badr Community college. Journal of Emerging Trends in Educational Research and Policy Studies (JETERAPS), 5(2),184-189.

Ta'amneh, M. (2017). The Effect of Using WhatsApp Messenger in Learning English Language among University Students. International Research in Education (IRE), 5,(1), 143-151.

Tella, A. (2011). Reliability and factor analysis of a blackboard course management system success: a scale development and validation in an educational context. Journal of Information Technology Education, 10(1), $55-80$.

Wahyuni, S.(2018). The Effect of Blended Learning Model towards Students' Writing Ability. Journal of English for Academic.5(2)97-111.

\section{Author}

Dr. Mohammad Abd Alhafeez Ali Ta'amneh is an Associate Professor of Teaching English as a Foreign Language (TEFL) at Taibah University. He received his Ph.D. in English Language Curriculum and Instruction from Yarmouk University in the Department of Curriculum and Instruction in Jordan in 2012. He had a master's degree in Teaching English as a Foreign Language (TEFL) from Hashemite University in Jordan in 2005, and a bachelor's degree in English language and Literature from Yarmouk University in Jordan in 2002. His research interests include applied linguistics, blended learning, language teaching, e-learning, language in use, and language analysis. 